\title{
Groundwater depletion embedded in domestic transfers and international exports of the United States
}

\author{
Sajani Gumidyala ${ }^{1}$, Paul J. Ruess ${ }^{1}$, Megan Konar*1, \\ Landon Marston ${ }^{2}$, Carole Dalin ${ }^{3}$, and Yoshihide Wada ${ }^{4}$ \\ ${ }^{1}$ Department of Civil and Environmental Engineering, \\ University of Illinois at Urbana-Champaign, 205 North Mathews Avenue, Urbana, IL 61801, USA \\ ${ }^{2}$ Department of Civil Engineering, \\ Kansas State University, 2137 Fiedler Hall, Manhattan, KS 66506, USA \\ ${ }^{3}$ Institute for Sustainable Resources, Bartlett School of Environment, Energy and Resources \\ University College London, Central House, 14 Upper Woburn Place, London, WC1H 0NN, UK \\ ${ }^{4}$ International Institute for Applied Systems Analysis (IIASA), \\ Schlossplatz 1, A-2361, Laxenburg, Austria
}

\begin{abstract}
The United States plays a key role in global food security by producing and exporting agricultural products. Groundwater irrigation is increasingly important in agricultural production, nearly tripling since records began in 1950. Increased reliance on groundwater and prolonged unsustainable pumping of aquifers has led to groundwater depletion in many areas. In this study, we ask: How much groundwater depletion is embedded in the domestic transfers and international agricultural exports of the United States? How much do domestic and international agricultural commodity fluxes rely on unsustainable groundwater use? To address these questions we quantify the amount of nonrenewable groundwater that is incorporated into agricultural commodities produced in the U.S. and transferred both within the country and exported internationally. We find that $26.3 \mathrm{~km}^{3}$ of nonrenewable groundwater was transferred domestically in 2002 and $2.7 \mathrm{~km}^{3}$ was sent abroad. In
\end{abstract}


2012, $34.8 \mathrm{~km}^{3}$ was transferred domestically and $3.7 \mathrm{~km}^{3}$ was exported. This indicates an increase of $32 \%$ in domestic transfers and $38 \%$ in international exports. In 2002, we find that 1,491,126 kilotonnes (340 billion \$USD) of agricultural products reliant on nonrenewable groundwater were domestically transferred, while 119,048 kilotonnes (47 billion \$USD) were exported. In 2012, the mass transfer of agricultural goods reliant on unsustainable groundwater decreased, but their value in national and international supply chains increased by $54 \%$ and $31 \%$, respectively. Our results underscore the importance of the long-term risks posed to global agricultural supply chains from reliance on unsustainable groundwater use.

\section{Introduction}

Groundwater is increasingly important to agricultural production, as factors such as climate change, population growth, increasing water demand, and rising consumption of meat lead to more demands on water resources worldwide (Vörösmarty et al., 2000; Mekonnen and Hoekstra, 2012; Wada et al., 2012). Groundwater is also critical for maintaining agricultural supply chains during times of drought (Marston and Konar, 2017). Groundwater depletion (GWD) occurs when groundwater abstraction exceeds the recharge rates of an aquifer over a persistent period of time, thus leading to unsustainable groundwater use (Wada et al., 2012). This is a particularly important concern for locations that cannot meet their water demands using only renewable water supplies ( Wada et al., 2012; Gleeson et al., 2012). Much GWD has been shown to support the international trade of agricultural commodities (Dalin et al., 2017). Here, we examine how GWD in the United States is incorporated into national transfers and international exports of agricultural commodities.

Most agricultural production both globally and within the U.S. is rainfed (Falkenmark and Rockström, 2004). However, agriculture is responsible for approximately $70 \%$ of freshwater withdrawals, and is by far the largest consumptive user of water resources ( $\sim 9 \%$ of consumptive demands) (Postel et al., 1996; Vörösmarty et al., 2000; Gleick and Palaniappan, 2010; Marston et al., 2018). Irrigation systems are critical to buffer extreme weather impacts on crop production (Troy et al., 2015) and to increase agricultural productivity (Davis et al., 2017). Water use in the agricultural sector is facing many challenges. Demands from other water users, such as industry, municipalities, and recreation - as well as the need to allocate water to environmental services - are increasing (McDonald et al., 2011). Additionally, changes in climate variability and extremes will alter both the availability and demand for water resources, making it potentially more difficult for farmers to grow crops as they have done in the past, which threatens food security (Schmidhuber and Tubiello, 2007; Hertel et al., 2010; Lobell et al., 2011). Amidst these competing demands and increased variability of surface supplies, farmers are increasingly turning to groundwater to irrigate their crops (Marston and Konar, 2017).

As a leading producer and exporter of staple agricultural commodities, the U.S. plays 
an important role in feeding the world (Ercsey-Ravasz et al., 2012; Konar et al., 2018). Over one third of the world's coarse grain (e.g. corn, barley, sorghum, oats and rye) and over $50 \%$ of the world's soybeans are produced by the United States (U.S. Department of Agriculture Foreign Agricultural Service, 2019a,b). The U.S. contributes a significant fraction of this production to global export markets. One third of the global export market in coarse grains is from the United States (U.S. Department of Agriculture Foreign Agricultural Service, 2019a). The U.S. contributes one third of soy to the world export market (U.S. Department of Agriculture Foreign Agricultural Service, 2019b). Coarse grain and soy crops are responsible for a large share of the world's food calorie intake (D'Odorico et al., 2014), making the U.S. an important contributor to global food security. Moreover, we have selected the U.S. for this study due to the availability of sub-national commodity flow data.

Much agricultural production and export in the U.S. has been enabled by irrigation from groundwater resources. The U.S. has the second highest rate of groundwater abstraction (Wagner, 2017; Esnault et al., 2014) and is the second largest GWD exporter worldwide (Dalin et al., 2017). Roughly $18 \%$ of the domestic grain supply of the U.S. is produced in locations in which the aquifers are being used unsustainably (Marston et al., 2015). Agricultural production that depends on unsustainable groundwater use will eventually become infeasible, once groundwater pumping reaches the physical or economic pumping constraints. It is therefore essential to understand the risks posed to domestic and international agricultural supply chains by the eventual declines in agricultural production from these locations. Here, we refer to domestic agricultural commodity transfers within the U.S. as 'transfers', and the associated GWD embedded in them as depletion water transfers (DWT). We use the term 'exports' to refer to agricultural commodity exports from the U.S. to other countries, and the associated GWD with these exports as depletion water exports (DWE). DWT and DWE enable us to assess the exposure of supply chains to GWD.

The main goal of this study is to understand how GWD is incorporated into complex national and international agricultural supply chains. Here, we assess the domestic and international agricultural commodity transfers of the United States that rely on unsustainable groundwater use. The main questions addressed by this study are: (1) How much groundwater depletion is embedded in the domestic transfers and exports of the United States? (2) How have virtual groundwater depletion transfers and exports changed over time? (3) What domestic locations are the largest sources of virtual groundwater depletion transfers and exports? (4) What is the mass and value of agricultural transfers and exports that rely on groundwater depletion? We present our methods in Section 2. We describe and discuss our results in Section 3. We conclude in Section 4. 


\section{Methods}

In this section, we first describe how we estimate crop-specific groundwater depletion (GWD) $\left[\mathrm{m}^{3}\right]$ within the United States. Second, we describe the U.S. government database of agricultural commodity transfers and exports. Then, we describe how we quantify the groundwater depletion embedded in transfers and exports. Finally, we explain major methodological assumptions and limitations. The spatial domain for this study is the Continental United States (CONUS), which excludes Alaska, Hawaii, and Puerto Rico. The focus of this study is the groundwater depletion embedded in agricultural transfers and exports, so we omit groundwater depletion associated with other economic sectors (e.g. industry, municipal use, etc.). Table 1 summarizes all data dependencies in this study.

\subsection{Groundwater depletion by crop}

We extract $0.5 \times 0.5$ degree grids of groundwater depletion (GWD) within the United States from the global study of Dalin et al. (2017). We use existing PCR-GLOBWB modeled GWD in this study because they are highly studied and validated (Wada et al., 2012, 2014; Dalin et al., 2017). Monthly GWD volumes were summed to arrive at annual values. This was done for the years 2000 and 2010. In this way, gridded, crop class-specific estimates of GWD $\left[\mathrm{km}^{3}\right.$ year $\left.{ }^{-1}\right]$ were obtained. To aggregate 0.5 degree grids to U.S. counties, an area-weighted sum of the pixels overlapping each U.S. county was calculated. County scale values were then aggregated to FAF4 (refer to Section 2.2) and state polygons. A U.S. county to FAF zone crosswalk table was obtained from Oak Ridge National Laboratory (https://www.ornl.gov/). Shapefiles for political boundaries within the U.S. were obtained from the U.S. Census Bureau website (https://www . census.gov/geo/maps-data/data/tiger-line.html).

The PCR-Global Water Balance (PCR-GLOBWB) model (Wada et al., 2012, 2014) was used to estimate GWD $\left[\mathrm{m}^{3}\right]$ in Dalin et al. (2017). PCR-GLOBWB is a global hydrological and water resources model that runs on a $0.5^{\circ}$ by $0.5^{\circ}$ global grid. PCR-GLOBWB groundwater abstractions include all groundwater used for industrial, domestic, and agricultural sectors (irrigation and livestock demand) (Wada et al., 2012). Groundwater abstraction estimates from PCR-GLOBWB have been extensively validated in previous studies. Simulated terrestrial water storage was compared against NASA Gravity Recovery and Climate Experiment (GRACE) satellite observations (Wada et al., 2012). Critically, groundwater abstraction values generated from PCR-GLOBWB are well validated within the United States (Wada et al., 2012). A time series of national groundwater abstraction and depletion values shows good agreement between PCR-GLOBWB and U.S. Geological Survey (USGS) data (Hutson et al., 2004; Maupin et al., 2014) (see Figure 3). Regional variations of surface water and groundwater withdrawal match reasonably well with reported subnational statistics for the U.S. (Wada et al., 2014). Groundwater ab- 
straction rates for the U.S. show good agreement with USGS county-level data on groundwater withdrawals (Maupin et al., 2014). Fig 1 maps PCR-GLOBWB model estimates of groundwater abstraction and USGS statistical information on groundwater withdrawals. Note that the comparison between PCR-GLOBWB and USGS for the year 2000 (Hutson et al., 2004) was already presented in Wada et al. (2012). Now, we additionally provide mapped comparison between PCR-GLOBWB and USGS for 2010 (Maupin et al., 2014). Fig 1 illustrates that PCR-GLOBWB captures the temporal and spatial distribution of groundwater use within the U.S. to a reasonable extent. Metrics that compare the spatial correlation of groundwater abstraction between PCR-GLOBWB and USGS are provided in Table 2 . Table 2 quantitatively indicates good spatial agreement between PCR-GLOBWB model estimates of groundwater abstractions over time.

To determine GWD for irrigation, the PCR-GLOBWB model was used to simulate crop water use for the 26 irrigated crop classes provided in the MIRCA2000 database (Portmann et al., 2010). MIRCA2000 provides information on 26 crop classes (listed in the Supporting Information), including crop-specific calendars and growing season lengths. Daily climate data (1979-2010) were retrieved from the ERA-Interim reanalysis, where the precipitation was corrected with GPCP precipitation (GPCP: Global Precipitation Climatology Project; http://www.gewex.org/gpcp.html) (Dee et al., 2011). The initial conditions of PCR-GLOBWB are obtained with at least a 50-year spin up, as is common practice (Sutanudjaja et al., 2018). The initial soil moisture conditions are modeled from 1960-2010 using only two crop types (paddy and non-paddy). A dynamic irrigation scheme was implemented in which paddy and nonpaddy crops were separately parameterized. This allows for the feedback between the application of irrigation water and the corresponding changes in surface and soil water balance to be considered.

These results are then used as model inputs for 2000 and 2010 in which groundwater depletion for all 26 crops is modeled. PCR-GLOBWB partitioned the surface water, groundwater, and soil moisture used to meet agricultural demand. Crop factors per grid cell were used to calculate reference and potential evapotranspiration, which were then used to calculate irrigation water demands for each crop. Irrigation water demand is the amount of water that needs to be additionally supplied to ensure maximum crop growth, taking irrigation losses (i.e. conveyance) into account. Irrigated cropland areas were taken from the MIRCA2000 dataset for the year 2000 and scaled to year 2010 using annual national irrigated cropland areas data from the Food and Agricultural Organization (FAO) (http://www.fao.org/faostat/en/\#data/RL). Maps on the comparison of irrigated areas between MIRCA and USDA are shown in Figure 2. Irrigated area compares reasonably well across states and time periods in MIRCA and USDA data sets. Table 3 provides spatial correlation indices between MIRCA and USDA, showing very good agreement (i.e. $\mathrm{R} 2=0.92$ in $2000 ; \mathrm{R} 2=0.87$ in 2010 ).

Surface water availability was calculated by subtracting upstream consumptive water use from agriculture, industry, livestock, and households from cumulative discharge along river networks at the daily time step from 1979-2010. We refer to Sutanudjaja et al. (2018) 
for detailed descriptions of river routing (i.e. kinematic wave). PCR-GLOBWB was then used to simulate natural groundwater recharge rates and combined with irrigation return flows, which were estimated based on soil properties such as hydraulic conductivity, country-specific irrigation efficiency factors, and irrigated crop areas. The sum of natural and irrigation recharge was used as total groundwater recharge. Grid-based groundwater abstraction for irrigation was then calculated on a monthly basis for each year based on the IGRAC reported country database (https://www.un-igrac.org/). Water demand was used as a proxy for downscaling reported country-level groundwater abstraction, and it was assumed that groundwater was used to satisfy the demand that could not be met with the available precipitation and surface water for that grid cell. If applicable, national desalination statistics were obtained for years 1960-2010 and then downscaled onto a global coastal ribbon of $\sim 40 \mathrm{~km}$ based on gridded population densities. Return flows were calculated for the industrial and domestic sectors based on recycling ratios calculated for each country. This coupling of water availability and water demand dynamically simulates actual water use at a daily time step rather than potential water demand that is independent of available water, and therefore accounting for interactions between human water use and terrestrial fluxes.

Finally, groundwater abstraction in excess of groundwater recharge was used to determine GWD. In order to distinguish nonrenewable groundwater abstraction from renewable water sources, the amount of groundwater pumped for each irrigated crop on the basis of crop growing areas and seasons is considered, including multicropping practices and subgrid variability of different crop types. Crop-specific groundwater abstraction in excess of simulated groundwater recharge is used to estimate GWD by crop.

\subsection{Agricultural production and supply chain data}

U.S. crop production data for the corresponding crops of each MIRCA crop class were obtained from the U.S. Department of Agriculture (USDA) National Agricultural Statistics Service (NASS) census (https://quickstats.nass.usda.gov/). County-level production data for the year 2012 and state-level data for 2002 was collected, since census data are only available for years ending with ' 2 ' and ' 7 '. All production units are converted to tons. Some data from USDA are suppressed in order to protect the privacy of farmers, more often at the county scale. In these instances, the sum of all available county production data are summed and subtracted from the state total, and this difference is uniformly distributed among all suppressed counties. State-level 2002 data were also taken from USDA census when available, and data for this year is also somewhat sparse. To make up for this, different techniques were used to estimate missing values. 2002 survey yield rates and harvested areas for the crop of interest were multiplied together to get tonnage of production for the state, or production values from preceding and succeeding years were averaged if available. In cases where neither of these methods were applicable, national-level production for the crop was taken from the Food and Agriculture Orga- 
nization (FAO) FAOSTAT database (http://www.fao.org/faostat/en/\#data/QC) for the year 2002, and state portions were scaled according to their 2012 production value distribution.

Commodity flow data are from the Freight Analysis Framework version 4 (FAF4) database $(F A F 4,2015)$. This database is provided by the U.S. Department of Transportation and represents a collaboration between the Bureau of Transportation Statistics and the Federal Highway Administration. FAF4 is built on 2012 Commodity Flow Survey (CFS) data $(C F S, 2013)$, which provides detailed information on the origin, destination, mode of transport, distance, and value (in USD and tons) for each transport link. FAF4 data is available for bilateral transfers between FAF4 zones, as well as eight international regions (refer to the Supporting Information for the list of world regions included by FAF4). There are 132 FAF4 zones in the U.S. and they represent a combination of Municipal Statistical Areas (MSAs) and Remainder of State (see Supporting Information for a map and list of FAF zones). FAF4 data are available for the years 1997, 2002, 2007, and 2012. For this study, we select the years 2002 and 2012, since they are the closest to the GWD estimates available from Dalin et al. (2017) for years 2000 and 2010. Note that FAF4 is available at the state spatial resolution for 2002 and FAF spatial resolution for 2012 (see Table 1).

The Standard Classification of Transported Goods (SCTG) coding system (https: //bhs.econ.census.gov) is used to classify commodity flows. A full list of the SCTG commodity classes is provided in the Supporting Information. Here, we select the 3 SCTG categories composed of raw agricultural goods. We select SCTG 2: cereal grains, SCTG 3: all other agricultural products excluding animal feed and forage products, and SCTG 4: animal feed and other products of animal origin. The MIRCA2000 crop classes are mapped to SCTG commodity categories in the Supporting Information. In this way, FAF4 supply chain information is relatively refined in its spatial resolution (e.g. sub-national), but has a relatively coarse commodity categorization (e.g. agricultural commodity classes, not specific crops).

\subsection{Groundwater depletion embedded in commodity flows}

Here, we describe how we calculate the amount of GWD embedded in domestic transfers and international exports. We refer to depletion water flows (DWF) as the generic term for GWD embedded in both domestic transfers and international exports. We calculate DWF as:

$$
D W F_{o, d, c, y}=G W D_{o, c, y} \times \frac{F_{o, d, c, y}}{\Sigma F_{o, c, y}}
$$

where $G W D$ is groundwater depletion $\left[\mathrm{m}^{3}\right], F$ is agricultural commodity flow mass (i.e. either domestic transfer or international export) [kilotonnes], $o$ is state or FAF zone of origin, $d$ is destination, $c$ is SCTG commodity group, and $y$ is year. Individual out-flows 
(e.g. $F_{o, d, c, y}$ indexed by an origin-destination pair) are normalized by all outflows (e.g. $F_{o, c, y}$, not indexed by destination). In this way, the GWD in each location of production is proportionally assigned to commodity fluxes and the amount of GWD exported from each region is bounded by the total GWD found by the physical model estimates.

GWD embodied in commodity transfers within the United States are referred to as depletion water transfers (DWT). GWD embodied in international exports are referred to as depletion water exports (DWE). Note that this approach makes two key assumptions: (1) that each trade flow is comprised of goods produced in the location of origin, and (2) that the composition of all outflows remains consistent regardless of the destination. For example, if Illinois sends SCTG 2: grains to both Florida and Colorado the proportion of corn in each bilateral link will be the same. This is despite the fact that Colorado may demand more corn from Illinois than does Florida. Note that a transfer may remain within the FAF zone of origin (i.e. a "self-loop").

\subsection{Assumptions}

One major limitation of our study is the temporal mismatch between available input data. We match GWD in 2000 with agricultural supply chain data for the year 2002. We match GWD in 2010 with agricultural data for the year 2012. GWD data by crop is only available for 2000 and 2010 from Dalin et al. (2017), while U.S. agricultural census information is available in years ending in ' 2 ' and '7' (see Table 1). This temporal mismatch is a major limitation of our statistical approach and our results would be improved if we had consistent time periods. However, groundwater use and depletion is relatively constant at the national scale for our study domain (refer to Supporting Information). This gives us confidence that our estimated values of GWD are appropriate to pair with the available supply chain statistics.

There are many assumptions that influence the GWD estimates. A notable PCRGLOBWB assumption is that of maximum crop growth, which will not always accurately reflect actual farming conditions. This assumption relies on optimal irrigation in the model to ensure no crop stress. This optimal irrigation assumption means that irrigation water demand may be overestimated in many cases. Of note, this maximum crop growth leads to another assumption that all irrigated areas are productive. Where a crop had irrigated area in 2000, it is assumed to again be grown in 2010 to maximum crop growth, regardless of whether these crops were actually moved (this is not captured by the FAOSTAT scaling we use) or were unproductive. Another relevant model assumption pertains to irrigation efficiency, or the volume of applied water that is taken up by crops. There is a single irrigation efficiency value for the entire US (Rohwer et al., 2007), which will miss technological differences in irrigation across the country. Additionally, the flux based method of PCR-GLOBWB ignores additional capture from surface supplies and does not consider available groundwater resources. Yet, PCR-GLOBWB is constrained by national statistics on groundwater use from IGRAC (see Section 2.4 of Wada et al. 
(2012) for details). This ensures that model estimates of groundwater use will be in a reasonably close range to national statistics, yet does not invalidate the comparison between PCR-GLOBWB pixels and county-scale USGS information, as these are spatially resolved and not used to force the model.

FAF data also comes with its own assumptions. Domestic production and consumption information underpins the FAF commodity transfers. However, FAF presents information on commodity transfers principally for transportation planning. For this reason, a new commodity flux is reported each time a commodity transformation occurs (i.e. corn to high fructose corn syrup). This means that production and consumption flows are not perfectly modeled and double counting of embodied resources is a potential issue. However, since we focus on agricultural commodities this issue of double counting will not be as problematic in this study. Additionally, we quantify virtual fluxes but do not transform our estimate values into water footprints of consumption largely for this reason.

Equation 1 indicates that we assign $G W D$ proportionately to out-fluxes. Note that commodity fluxes are provided by SCTG commodity categories while GWD values are estimated for specific crops. To twin SCTG commodity categories of FAF fluxes with GWD estimates we assume that the commodity composition of all outflows is the same regardless of the destination. The values of SCTG commodity fluxes vary by destination. However, our approach assumes that the crops contained within each SCTG commodity category (e.g. corn within SCTG 2) will be distributed to locations in the same proportion. This assumption is necessary because we do not have information on the fluxes of specific crops, but only the fluxes of SCTG commodity categories. Importantly, our approach ensures that the volume of GWD assigned to each outflow does not exceed the physical volume of GWD estimated by the PCR-GLOBWB model.

We assume that SCTG 4 is made up entirely of animal feed and do not explicitly model eggs, honey, or any other products of animal origin. This assumption is supported by production data on animal feed, hay and haylage, and other animal products from the U.S. Department of Agriculture (USDA) Economic Research Service (https: //data.ers.usda.gov/FEED-GRAINS-custom-query.aspx) and USDA-NASS (https: //quickstats.nass.usda.gov/). National level annual data on these groups were compared when available (e.g. for 2011, 2012, and 2015) and animal feed was estimated to comprise over $95 \%$ of the total tonnage for USDA classes that fall under the SCTG4 category. Then, we paired SCTG 4 with the MIRCA class 'Managed grassland/pasture'. In this way we assume that the vast majority of GWD of this commodity class is due to animal feed, and that other products of animal origin (i.e. animal hair, bones, wool) are negligible in comparison. 


\section{Results and discussion}

\subsection{How much groundwater depletion is embedded in U.S. trans- fers and exports?}

We present GWD at the county spatial scale for 2000 and 2010 (see Fig 4). Fig 4 illustrates that most GWD occurs in the western portion of the U.S., since this part of the country is heavily irrigated under a more arid climate. Correspondingly, Western states have large depletion water footprints (see Table 4). Arizona has the largest depletion water footprint (398 $\left[\mathrm{m}^{3} /\right.$ ton $\left.]\right)$, followed by Texas $\left(210\left[\mathrm{~m}^{3} /\right.\right.$ ton $\left.]\right)$, and Colorado $\left(196\left[\mathrm{~m}^{3} /\right.\right.$ ton $\left.]\right)$.

Fig 4 illustrates that GWD has increased in key aquifers in the United States. In particular, the Central Valley aquifer in central and southern California and the High Plains aquifer along the eastern edge of the Rocky Mountains have experienced increasing levels of GWD, as we would expect. Importantly, major groundwater aquifers show the greatest increase in GWD over the course of the decade (see Fig 4B). According to a USGS report, these three major aquifer regions contributed to $67 \%$ of U.S. GWD between 1900 and 2008, while that statistic jumps to $93 \%$ of national GWD when restricted to the time period from 2000 to 2008 (Konikow, 2013).

We estimate the total volume of groundwater depletion in 2000 to be $29.1 \mathrm{~km}^{3}$, while total GWD in 2010 is $38.5 \mathrm{~km}^{3}$ (refer to Table 5). For comparison, Marston et al. (2015) found $33.89 \mathrm{~km}^{3}$ of total groundwater was consumed for crop production within the High Plains (17.93), Mississippi Embayment (9.18), and Central Valley (6.81) aquifer systems for the year 2007. Note that the current study accounts for groundwater depletion in all locations throughout the U.S., whereas Marston et al. (2015) only accounted for the three most depleted aquifers. USGS reports crop groundwater withdrawals from counties overlying these aquifers as $46.31 \mathrm{~km}^{3}$ for the year 2005 .

Fig 1 shows that spatially resolved estimates of groundwater abstraction compare well with USGS groundwater use data. However, we require modeled estimates of crop-specific groundwater depletion for this study, and these data are not as readily available in the USGS data across the nation. Discrepancies between modeled estimates and USGS data on GWD occur over the Mississippi Embayment region in particular. The Mississippi Embayment aquifer is not captured as well by our model estimates, likely due to the specific crops that we consider. Modeled estimates show a much smaller spatial range of depletion over this aquifer region than USGS data show (Konikow, 2013; Clark et al., 2011) (see Fig 4). Any inconsistencies in GWD estimates will carry through all of our estimates of GWD transfers and exports. Despite this, these GWD estimates are currently the best available option due to being crop-specific and highly resolved in space.

The total amount of GWD embedded in flows was $29.1 \mathrm{~km}^{3}$ in 2002. Of this total, 26.3 $\mathrm{km}^{3}$ is DWT and $2.7 \mathrm{~km}^{3}$ are DWE. This means that approximately $91 \%$ of all groundwater depletion is embedded in domestic transfers and $9 \%$ is embedded in international exports in 2002. The total volume of GWD embedded in transfers and exports was 38.5 
$\mathrm{km}^{3}$ for 2012 , of which $34.8 \mathrm{~km}^{3}$ are DWT and $3.74 \mathrm{~km}^{3}$ are DWE. This means that an (unsustainable) volume roughly the size of Lake Mead was transferred domestically in 2012 (Lake Mead is $35.7 \mathrm{~km}^{3}$ ). For 2012, approximately 90\% of groundwater depletion flows was embedded in domestic transfers, while $10 \%$ was shipped abroad.

\subsection{How has embedded groundwater depletion changed over time?}

GWD for irrigation in the U.S. has increased over time. From 2000 to 2010 there was a $32.7 \%$ increase in GWD overall. GWD changes in time across the U.S. in a spatially heterogeneous way. For the most part, large areas of the western U.S. have reduced their GWD (note the many green and blue counties in Fig 4). However, GWD increases are particularly pronounced in portions of the Central Valley and High Plains aquifers. There are also significant increases in GWD for southern Arizona, areas of Nevada, Utah, Wyoming, Idaho, and Florida between 2000 and 2010 (see Fig 4).

Despite declines in state average domestic agricultural transfers, the total volume of GWD embedded in transfers increased by $32.1 \%$ (26.3 $\mathrm{km}^{3}$ in 2002 to $34.8 \mathrm{~km}^{3}$ in 2012). Total DWE increased by $38.0 \%\left(2.7 \mathrm{~km}^{3}\right.$ in 2002 to $3.7 \mathrm{~km}^{3}$ in 2012; see Table 5). The SCTG group with the highest increase in total volume for DWT was SCTG 2 cereal grains at a $58.5 \%$ increase (see Table 6 ). SCTG 4 animal products had the highest increase in total volume for DWE with a $144.4 \%$ increase. DWE for cereal grains was the only group to have a decrease in total volume traded, with a 3.2\% decrease between 2002 and 2012.

Table 5 shows that an average of $34.8 \mathrm{~km}^{3}$ GWD was transferred domestically in 2010 . The average volume of GWD exported across all states and commodity groups in 2010 was $3.74 \mathrm{~km}^{3}$. By SCTG group, the highest state average of GWD in domestic transfers is for animal products in both 2000 and 2010. In 2000 the mean was $11.06 \mathrm{~km}^{3}$ and in 2010 a mean of $13.76 \mathrm{~km}^{3}$ was transferred (refer to Table 6). The highest mean for international exports by state was associated with SCTG 3 for both years, with $1.32 \mathrm{~km}^{3}$ in 2000 and $1.66 \mathrm{~km}^{3}$ in 2010 .

Mean GWD embedded in flows has increased between the two study years (see Table 5). This is despite declines in total agricultural transfers over time. This indicates that both domestic agricultural transfers and international exports are originating more in locations that deplete groundwater and/or production locations are more intensively relying on fossil groundwater. In other words, agricultural commodity fluxes have become increasingly reliant on GWD. The cross-sectional variance of GWD in transfers and exports is increasing over time. This indicates that the GWD in transfers and exports is becoming more heterogeneous over time, with some production locations using even more unsustainable groundwater. This same trend is observed in DWT for all SCTG groups and DWE of SCTG 4 (refer to Table 6). However, means and variances of DWE for SCTG 2 decreased. This means that GWD is increasingly being used for higher value agricultural transfers and exports. 


\subsection{What locations exchange the most groundwater depletion?}

Western states are the largest sources of virtual GWD (see Figs 5 and 6), corresponding to spatial patterns of GWD in production (see Fig 4). Table 7 ranks states by their DWT. California by far transfers the most GWD, despite not having the largest depletion water footprint (see Table 4). California does have the largest agricultural production, leading it to also have the largest total volume of GWD. The outflow of GWD from California was $13.1 \mathrm{~km}^{3}$ in 2012 . However, Fig 7 makes it clear that California actually uses most of its own GWD. In fact, all of the major GWD transfer states retain the majority of their GWD. It is important to note that only raw crop products and animal feed are included in this study. These products are often sourced locally as input into higher value products (i.e. meat, textiles, processed foods), which are then shipped elsewhere for final consumption. The importance of GWD to the California economy is consistent with other studies (Marston and Konar, 2017; Marston et al., 2018).

Fig 8 shows changes in DWT from 2002 to 2012. Fig 8A presents positive changes (i.e. more GWD in transfers from 2000 to 2010) while Fig 8B presents negative changes (i.e. less GWD in transfers from 2000 to 2010). The volume in Fig 8A is $11.8 \mathrm{~km}^{3}$, while the volume in Fig 8B is $3.4 \mathrm{~km}^{3}$. Mississippi had no outflows of GWD in 2000, but saw a large increase in 2010. Pennsylvania, Delaware, and Michigan were the opposite, and decreased by $100 \%$ in all SCTG categories. States that had the largest gains in DWT include Nebraska, Utah, Idaho, Wyoming, Montana, Colorado, and California. Arkansas, Florida, and Arizona also saw major increases in DWT. California has the highest increase in GWD transfers, an increase of $2.9 \mathrm{~km}^{3}$ from 2002 to 2012 (see Fig 8), followed by Nebraska with an increase of $1.5 \mathrm{~km}^{3}$. Note that groundwater played an even more critical role to agricultural supply chains originating in the Central Valley of California during the drought of 2012-2014 (Marston and Konar, 2017).

Fig 9 shows DWE for the year 2012. California and Texas are the two largest states in terms of DWE. However, note that the volume of DWE captured by this graph (i.e. 3.7 $\mathrm{km}^{3}$ ) is much smaller than the volume of DWT captured in Fig 7 (i.e. $34.8 \mathrm{~km}^{3}$ ). DWE to the eight major world regions are shown in Fig 9. East Asia is the top recipient of GWD, followed by Canada, Mexico, and Central Asia. Southeast Asia, Africa, Europe, and Rest of the Americas receive relatively small volumes of GWD in their imports from the United States. This highlights that certain world regions may have more exposure to production risk from falling water tables in their supply chains than other world regions.

Fig 10 shows the changes in DWE. California exhibits the most significant increase, while Wyoming and Colorado have the largest reduction. Despite this reduction, Colorado remains a top contributor to DWE in 2012. Arizona, followed by New York, export less GWD in 2012, after exporting to all eight world regions in 2002. California significantly shifted DWE patterns in 2012, changing its largest destinations from Europe, Africa, and Rest of the Americas to primarily East Asia, followed by Central Asia and Canada. Despite East Asia being the top destination for GWD only in 2010, it is the top destination 
for agricultural exports in terms of mass for both years. Upon further investigation of the types of products California exports to East Asia, FAF4 data shows that SCTG4 made up the majority of exports to East Asia in 2002, while in 2012, the mass of SCTG 3 went from the least amount exported to the most. This is despite the mass of SCTG 4 exports increasing during the decade as well. This shows that GWD has become more important for fresh produce production and exports over time.

\subsection{What food flows are reliant on groundwater depletion?}

The mass of food in the national and international agricultural supply chain that relies on groundwater depletion has decreased over time (see Table 8). Agricultural products reliant on nonrenewable groundwater domestically transferred was 1,491,126 kilotonnes in 2002 , falling to $1,412,242$ kilotonnes in 2012. This is a decrease of 78,884 kilotonnes, or a $5.3 \%$ decrease, in agricultural products reliant on GWD that were transferred within the U.S. Similarly, 119,048 kilotonnes of agricultural products reliant on GWD were exported in 2002, while 94,247 kilotonnes were exported in 2010. This is a decrease of $20.8 \%$ in mass terms. For comparison, the mass of production reliant on GWD decreased by 11.5\%. The top five crop classes reliant on GWD for production in terms of mass for 2002 were maize, followed by grasslands/pastures, citrus, soybeans, and wheat. In 2012, the crops that were most reliant on GWD were vegetables, fruits, and nuts, followed by grasslands/pastures, maize in fourth, and wheat again at fifth most.

Conversely, the dollar value of agricultural commodities in both national and international agricultural supply chains has increased (see Table 8). The value of agriculture in the U.S. supply chain has increased from 340 billion \$USD in 2002 to 524 billion \$USD in 2012. This is an increase of $\$ 183$ billion, or $54 \%$. This means that all but $\$ 2$ billion of the increase over the course of the decade required GWD to produce in some amount. Similarly, the value in the international trade system increased from 47,036 million $\$$ USD in 2002 to 61,808 million $\$$ USD in 2012 , an increase of $\$ 14.8$ billion, or a $31 \%$ increase. For both transfers and exports as well as both years, SCTG 3 makes up the largest component of commodities that are reliant on GWD in terms of \$USD. This is despite SCTG 2 making up the largest component of commodities reliant on GWD in terms of mass across both transfers and exports and both years. This indicates that groundwater depletion is increasingly being allocated to higher value crops, as was shown for California during drought (Marston and Konar, 2017). Importantly, we capture this transition to using GWD for higher-value agricultural goods despite the fact that we do not use GWD for the drought period (2012-2015). These higher-value agricultural goods - goods that fall into the SCTG3 class and also became the top GWD-intensive MIRCA classes for 2012 are also more water-intensive to produce. Not only is depleted groundwater increasingly being allocated to higher-value crops, they are being allocated to crops that demand more water to produce per unit of mass (Marston and Konar, 2017). Hence, overall GWD for agriculture increases, despite the fact that the mass of agricultural goods produced has 
decreased.

Table 9 provides a ranked list of links by their mass and dollar values for both transfers and exports. The largest link transfers that rely on GWD are all intra-state transfers in terms of both mass and value. For example, Iowa-Iowa is the largest link in terms of DWT by mass $(128,610$ [kilotonnes]), followed by Illinois-Illinois (103,195 [kilotonnes]), and Minnesota-Minnesota (101,052 [kilotonnes]). The California-California link is the fifth most in mass but the most highly valued (45,075 [million \$USD]). Iowa-Iowa (34,874 [million \$USD]), Illinois-Illinois (29,580 [million \$USD]), and Minnesota-Minnesota $(24,481$ [million $\$ \mathrm{USD}]$ ) are also the most valuable transfers that depend on GWD. The top DWE are from West Coast ports to East Asia in both mass and value units. Other large export links are from the Central U.S. ports to Mexico and Canada. Exports to Southeast Asia and Oceania are the fifth and ninth largest in mass, but are not in the top ten for value.

\subsection{Limitations of the study}

A major limitation of our study is that input data are not available for the same time period. We pair GWD data for 2000 and 2010 with FAF information on agricultural fluxes for 2002 and 2012, respectively. National groundwater use exhibits a relatively stable trend (see Supporting Information). However, this will mask local temporal variations that are likely to be important. We are confident that our results are conservative for two major reasons. First, PCR-GLOBWB underestimates GWD in the Mississippi Embayment aquifer area. This means that we are not estimating a large volume of GWD in national and international agricultural fluxes associated with this aquifer. Our study would be improved by better estimates of GWD in the Mississippi Embayment. However, it is preferable to provide conservative values, which is what we do. Future work might consider using USGS information on depletion in the Mississippi Embayment (Konikow, 2013) to scale PCR-GLOBWB output.

Second, we use GWD values for 2010 with 2012 flux data. The year 2012 marked the start of a severe drought in California, in which groundwater use increased in the Central Valley, leading to greater virtual groundwater exports (Marston and Konar, 2017). It is likely that much of this was from unsustainable sources. So, we again underestimate the GWD embedded in domestic transfers and exports. Additionally, we do not include grapes in our study (see the SI), which farmers increasingly planted over the course of the drought in California, in order to obtain more revenue per unit of irrigation water (Marston and Konar, 2017). Limitations in the match between MIRCA and SCTG crop categories, and coarse commodity flux information, limits our ability to assess GWD embedded in the supply chains of specific crops, an issue which is likely to be more pronounced for cash crops.

Another important limitation of our study is that it focuses solely on agricultural production and supply chains. This will underestimate the value of GWD to national and global supply chains. Agricultural products will be processed and refined into more 
complex agri-food/fuel items. By only quantifying the GWD embedded in agricultural supply chains, we are missing the potentially important role of groundwater to higher level commodities. However, restricting our study to only agricultural items has the benefit of minimizing double counting of groundwater embodied in the supply chain. The FAF4 supply chain data does not provide explicit production and consumption fluxes. This means that double counting is a problem when items are processed and refined. We avoid this issue by focusing only on raw crop items. Future work that disentangles the production and consumption accounting would further our understanding of the true role of groundwater in all agri-food/fuel supply chains.

Future work could improve the inclusion of local information into a groundwater model. We used the PCR-GLOBWB model which relies on several global inputs. However, more local information is available for the United States, that would improve the accuracy of groundwater modeling. For example, our input grids of crop locations were based on MIRCA rather than USDA county-scale statistics of crop areas. Similarly, time-varying crop calendars would enable physical models to better assess crop water demands during the growing season, rather than the crop calendars fixed circa 2000 in MIRCA. Configuring PCR-GLOBWB is beyond the scope of the current study, whose main objective is to bring GWD estimates together with agricultural flux data. Refined estimates of GWD based on local government data would improve our estimates of GWD in this important country. Additionally, future research could use more spatially-resolved estimates of the agri-food supply chain of the United States (Lin et al., 2019).

\section{Conclusion}

In this study, we quantified the volume of groundwater depletion embedded in U.S. domestic transfers and exports. Results reveal that there have been large increases in groundwater depletion transfers domestically via fresh produce transfers and internationally via animal feed exports. Between 2002 and 2012, the total volume of groundwater depletion embedded in U.S. domestic transfers increased by $32.1 \%$ and groundwater depletion embedded in international exports of the U.S. increased by $38.0 \%$. California contributes the most groundwater depletion to both the national and international agricultural supply chains of the United States, and is the largest consumer of its own groundwater depletion. East Asia imports the most embedded groundwater depletion of any world region, with $1.62 \mathrm{~km}^{3}$ imported.

The mass of food in the national and international agricultural supply chain of the U.S. that relies on groundwater depletion has decreased over time. 1,491,126 kilotonnes of agricultural products reliant on nonrenewable groundwater was domestically transferred in 2002, falling to 1,412,242 kilotonnes in 2012. Similarly, 119,048 kilotonnes was exported in 2002, while 94,247 kilotonnes was exported in 2012. However, the value of agricultural commodities in both national and international agricultural supply chains has increased. 
The value of agriculture in the U.S. supply chain has increased from 340,407 million \$USD in 2002 to 523,926 million \$USD in 2012 (a 54\% increase) while the value in the international trade system increased from 47,036 million \$USD in 2002 to 61,808 million \$USD in 2012 (a 31\% increase). This indicates that there has been an increase in the groundwater depletion footprint of agricultural commodities and that (unsustainable) groundwater use is increasingly being allocated to higher value crops.

This study shows that large volumes of groundwater depletion are embedded in the national agricultural supply chain of the United States, as well as in its international exports. The volume of unsustainable groundwater resources in these supply chains has increased over time. However, it is unclear if trade is driving overexploitation of groundwater resources. It is possible that even more groundwater would be unsustainably mined in an agricultural system without trade (i.e. one of 'self-sufficiency' or 'autarky'). Would more or less groundwater be depleted in the absence of trade? To determine if trade is leading to more groundwater being unsustainably used, we would need to use causal inference techniques, such as those employed by Dang and Konar (2018). We call for future work to examine the causal impact of trade on groundwater depletion.

Eventually, the mass and value of agricultural commodities produced with unsustainable groundwater will need to be replaced with production from elsewhere, once the groundwater reserves are no longer viable to mine. The groundwater depletion embedded in agricultural supply chains represents its exposure to unsustainable water use. Future research should assess the vulnerability of agricultural supply chains to unsustainable water use. Exposure to long-term water risk is one factor that may be important to consider in a cost-benefit assessment of agricultural policies. Going forward, researchers, policy makers, and supply chain managers should assess the threats posed to future food supply chains from depleted groundwater reserves.

\section{Acknowledgments}

This material is based upon work supported by the National Science Foundation Grant No. ACI-1639529 ("INFEWS/T1: Mesoscale Data Fusion to Map and Model the U.S. Food, Energy, and Water (FEW) System"), EAR-1534544 ("Hazards SEES: Understanding Cross-Scale Interactions of Trade and Food Policy to Improve Resilience to Drought Risk"), and CBET-1844773 ("CAREER: A National Strategy for a Resilient Food Supply Chain"). Any opinions, findings, and conclusions or recommendations expressed in this material are those of the author(s) and do not necessarily reflect the views of the National Science Foundation. All data sources are listed in the methods section of the paper and are freely available online. Please note that we provide key variables estimated in this study in the Supporting Information document in an effort to enable research reproducibility. 


\section{References}

CFS (2013), Commodity Flow Survey, http : //www.census.gov/econ/cfs/.

Clark, B. R., R. M. Hart, and J. J. Gurdak (2011), Groundwater Availability of the Mississippi Embayment, U.S. Geological Survey professional paper, 1785, 1-62.

Dalin, C., Y. Wada, T. Kastner, and M. J. Puma (2017), Groundwater depletion embedded in international food trade, Nature Publishing Group, 543(7647), 700-704, doi: 10.1038/nature21403.

Dang, Q., and M. Konar (2018), Trade Openness and Domestic Water Use, Water Resources Research, 54(1), doi:10.1002/2017WR021102.

Davis, K. F., M. C. Rulli, F. Garrassino, D. Chiarelli, A. Seveso, and P. DOdorico (2017), Water limits to closing yield gaps, Advances in Water Resources, 99, 6775, doi:10.1016/ j.advwatres.2016.11.015.

Dee, D. P., S. M. Uppala, A. J. Simmons, P. Berrisford, P. Poli, S. Kobayashi, U. Andrae, M. A. Balmaseda, G. Balsamo, P. Bauer, P. Bechtold, A. C. M. Beljaars, L. V. D. Berg, J. Bidlot, N. Bormann, C. Delsol, R. Dragani, M. Fuentes, A. J. Geer, and D. P. Dee (2011), The ERA-Interim reanalysis : configuration and performance of the data assimilation system, Quarterly Journal of the Royal Meteorological Society, 137(656), 553-597, doi:10.1002/qj.828.

D'Odorico, P., J. A. Carr, F. Laio, L. Ridolfi, and S. Vandoni (2014), Feeding humanity through global food trade, Earth's Future, 2(9), doi:10.1002/2014EF000250.

Ercsey-Ravasz, M., Z. Toroczkai, Z. Lakner, and J. Baranyi (2012), Complexity of the International Agro-Food Trade Network and Its Impact on Food Safety, PLoS ONE, 10(7), doi:10.1371/journal.pone.0037810.

Esnault, L., T. Gleeson, Y. Wada, J. Heinke, D. Gerten, E. Flanary, M. F. P. Bierkens, and L. P. H. V. Beek (2014), Linking groundwater use and stress to specific crops using the groundwater footprint in the Central Valley and High Plains aquifer systems, U.S., Water Resources Research, 50(6), 4953-4973, doi:10.1002/2013WR014792.Received.

FAF4 (2015), Freight Analysis Framework version 4, http://faf .ornl.gov/fafweb/.

Falkenmark, M., and J. Rockström (2004), Balancing water for humans and nature, Earthscan.

Gleeson, T., Y. Wada, M. F. Bierkens, and L. P. V. Beek (2012), Water balance of global aquifers revealed by groundwater footprint, Nature, 488(7410), 197-200, doi: 10.1038/nature11295. 
Gleick, P., and M. Palaniappan (2010), Inaugural Article: Peak water limits to freshwater withdrawal and use, PNAS, 107(25), 11,155-11,162.

Hertel, T., M. Burke, and D. Lobell (2010), The poverty implications of climate-induced crop yield changes by 2030, Global Environmental Change, 20(4), 577-585.

Hutson, S. S., N. L. Barber, J. F. Kenny, K. S. Linsey, D. S. Lumia, and M. A. Maupin (2004), Estimated use of water in the united states in 2000, Tech. Rep. Circular 1268.

Konar, M., X. Lin, B. Ruddell, and M. Sivapalan (2018), Scaling properties of food flow networks, PLoS ONE, 13(7), doi:10.1371/journal.pone.0199498.

Konikow, L. F. (2013), Groundwater depletion in the united states (1900-2008), Tech. Rep. U.S. Geological Survey Scientific Investigations Report $2013 ? 5079$.

Lin, X., P. J. Ruess, L. Marston, and M. Konar (2019), Food flows between counties in the United States, Environmental Research Letters, 14(084011), doi:10.1088/1748-9326/ ab29ae.

Lobell, D., W. Schlenker, and J. Costa-Roberts (2011), Climate trends and global crop production since 1980, Science.

Marston, L., and M. Konar (2017), Drought impacts to water footprints and virtual water transfers of the Central Valley of California, Water Resources Research, 53(7), 5756-5773, doi:10.1002/2016WR020251.Received.

Marston, L., M. Konar, X. Cai, and T. J. Troy (2015), Virtual groundwater transfers from overexploited aquifers in the United States Virtual groundwater transfers from overexploited aquifers in the United States, Proceedings of the National Academy of Sciences of the United States of America, 112(28), 8561-8566, doi:10.1073/pnas.1500457112.

Marston, L., Y. Ao, M. Konar, M. M. Mekonnen, and A. Y. Hoekstra (2018), HighResolution Water Footprints of Production of the United States, Water Resources Research, 54(3), 2288-2316, doi:10.1002/2017WR021923.

Maupin, M. A., J. F. Kenny, S. S. Hutson, J. K. Lovelace, N. L. Barber, and K. S. Linsey (2014), Estimated use of water in the united states in 2010, Tech. Rep. Circular 1405, doi:10.3133/cir1405.

McDonald, R. I., P. Green, D. Balk, B. M. Fekete, C. Revenga, M. Todd, and M. Montgomery (2011), Urban growth, climate change, and freshwater availability, Proc. Nat. Acad. Sci., 108(15), 6312-6317, doi:10.1073/pnas.1011615108.

Mekonnen, M. M., and A. Y. Hoekstra (2012), A Global Assessment of the Water Footprint of Farm Animal Products, Ecosystems, 15(3), 401-415, doi:10.1007/ s10021-011-9517-8. 
Portmann, F. T., S. Siebert, and P. Döll (2010), MIRCA2000Global monthly irrigated and rainfed crop areas around the year 2000: A new high?resolution data set for agricultural and hydrological modeling, Global Biogeochemical Cycles, 24(1), 1-24, doi:10.1029/ 2008 GB003435.

Postel, S. L., G. C. Daily, and P. R. Ehrlich (1996), Human appropriation of renewable fresh water, Science-AAAS-Weekly Paper Edition, 271 (5250), 785-787.

Rohwer, J., D. Gerten, and W. Lucht (2007), Development of functional irrigation types for improved global crop modelling, Tech. Rep. PIK Report No 104.

Schmidhuber, J., and F. N. Tubiello (2007), Global food security under climate change, Proceedings Of The National Academy Of Sciences Of The United States Of America, $104(50), 19,703-19,708$.

Sutanudjaja, V. B. R. W. N. W. Y. B. J. D. N. E. R. D. G. I. H. J. J. K., E.H., L. L. P. P. S. S. O. S. M. V. E. W. D. Karssenberg, D., and M. Bierkens (2018), PCRGLOBWB 2: a 5 arcmin global hydrological and water resources model, Geoscientific Model Development, 11 (6), 2429-2453.

Troy, T., C. Kipgen, and I. Pal (2015), The impact of climate extremes and irrigation on us crop yields, Environmental Research Letters, 10, 054,013, doi:10.1088/1748-9326/ 10/5/054013.

U.S. Department of Agriculture Foreign Agricultural Service (2019a), Coarse grains, https://apps.fas.usda.gov/psdonline/circulars/grain-corn-coarsegrains . pdf.

U.S. Department of Agriculture Foreign Agricultural Service (2019b), Oilseeds: World markets and trade, https://apps.fas.usda.gov/psdonline/circulars/oilseeds. pdf.

Vörösmarty, C. J., P. Green, J. Salisbury, and R. B. Lammers (2000), Global water resources: Vulnerability from climate change and population growth, Science, 289(5477), 284-288, doi:10.1126/science.289.5477.284.

Wada, Y., L. P. H. Van Beek, and M. F. P. Bierkens (2012), Nonsustainable groundwater sustaining irrigation: A global assessment, Water Resources Research, 48(6), 1-18, doi:10.1029/2011WR010562.

Wada, Y., D. Wisser, and M. F. P. Bierkens (2014), Global modeling of withdrawal, allocation and consumptive use of surface water and groundwater resources, Earth System Dynamics, 5(1), 15-40, doi:10.5194/esd-5-15-2014.

Wagner, K. L. (2017), Assessing Irrigation Aquifer Depletion: Introduction, Contemporary Water Research \& Education, 162(1), 1-3, doi:10.1111/j.1936-704X.2017.03255.x. 


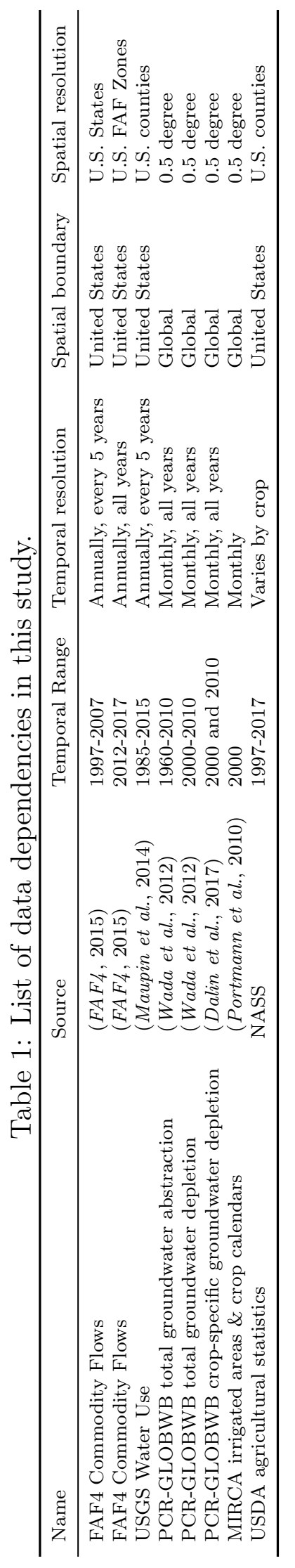


Table 2: Correlation metrics between groundwater abstraction as reported by PCRGLOBWB and USGS. Metrics are provided for both 2000 and 2010. 'R2' is R-squared value; 'R2 Adjusted' is adjusted R-squared value; 'MAE' is mean absolute error; 'RMSE' is root mean squared error; 'Jaccard' is the Jaccard similarity index; and 'SMC' is the simple matching coefficient.

\begin{tabular}{lllllll}
\hline Year & R2 & R2 Adjusted & MAE & RMSE & Jaccard & SMC \\
\hline 2000 & 0.65 & 0.65 & 20.77 & 70.37 & 0.96 & 0.96 \\
2010 & 0.54 & 0.54 & 22.19 & 79.48 & 0.99 & 0.99 \\
\hline
\end{tabular}


Table 3: Correlation metrics between irrigated area as reported by MIRCA and USDA. Metrics are provided for both 2000 and 2010. 'R2' is R-squared value; 'R2 Adjusted' is adjusted R-squared value; 'MAE' is mean absolute error; 'RMSE' is root mean squared error; 'Jaccard' is the Jaccard similarity index; and 'SMC' is the simple matching coefficient.

\begin{tabular}{lllllll}
\hline Year & R2 & R2 Adjusted & MAE & RMSE & Jaccard & SMC \\
\hline 2000 & 0.92 & 0.92 & 127143.26 & 332514.57 & 0.98 & 0.98 \\
2010 & 0.87 & 0.87 & 147900.69 & 372134.74 & 1.00 & 1.00 \\
\hline
\end{tabular}


Table 4: States with the most groundwater depletion in 2012. The top 10 states in terms of GWD are provided along with their total agricultural production [tons] and depletion footprint $\left[\mathrm{m}^{3} /\right.$ ton $]$.

\begin{tabular}{lllll}
\hline Rank & State & $\begin{array}{l}\text { Total GWD } \\
{\left[\mathrm{m}^{3} \times 10^{\wedge} 6\right]}\end{array}$ & $\begin{array}{l}\text { Total Production } \\
{[\text { tons }]}\end{array}$ & $\begin{array}{l}\text { Depletion footprint } \\
{\left[\mathrm{m}^{3} / \text { ton }\right]}\end{array}$ \\
\hline 1 & California & 14,886 & $83,480,978$ & 178 \\
2 & Texas & 5,554 & $26,468,531$ & 210 \\
3 & Colorado & 2,634 & $13,449,191$ & 196 \\
4 & Nebraska & 2,468 & $49,017,580$ & 50 \\
5 & Arizona & 2,468 & $6,197,385$ & 398 \\
6 & Idaho & 1,959 & $27,321,870$ & 72 \\
7 & Kansas & 1,040 & $32,291,438$ & 32 \\
8 & Arizona & 1,017 & $15,803,537$ & 64 \\
9 & Washington & 670 & $18,548,859$ & 36 \\
10 & New Jersey & 217 & $1,431,924$ & 152 \\
\hline
\end{tabular}


Table 5: Summary statistics of key variables in 2002 and 2012. The total, mean, and variance across states are provided for groundwater depletion (GWD) $\left[\mathrm{km}^{3}\right]$, total domestic transfers of agricultural items [kilotonnes], GWD embedded in domestic agricultural transfers $\left[\mathrm{km}^{3}\right]$, total international agricultural exports [kilotonnes], and GWD embedded in international agricultural exports $\left[\mathrm{km}^{3}\right]$.

\begin{tabular}{llllll}
\hline & $\begin{array}{l}\text { GWD } \\
{\left[\mathrm{km}^{3}\right]}\end{array}$ & $\begin{array}{l}\text { Agricultural } \\
\text { transfers [kilotonnes] }]\end{array}$ & $\begin{array}{l}\text { GWD transfers } \\
{\left[\mathrm{km}^{3}\right]}\end{array}$ & $\begin{array}{l}\text { Agricultural } \\
\text { exports [kilotonnes] }\end{array}$ & $\begin{array}{l}\text { GWD exports } \\
{\left[\mathrm{km}^{3}\right]}\end{array}$ \\
\hline 2002 Total & 29.1 & $1,754,910$ & 26.3 & 144,125 & 2.71 \\
2002 Mean & 0.581 & 35,098 & 0.527 & 2,883 & 0.054 \\
2002 Variance & 3.17 & $1,363,459,770$ & 2.485 & $29,972,974$ & 0.045 \\
\hline 2012 Total & 38.5 & $1,596,027$ & 34.8 & 155,519 & 3.74 \\
2012 Mean & 0.771 & 31,921 & 0.696 & 3,110 & 0.075 \\
2012 Variance & 5.043 & $1,622,203,009$ & 3.927 & $79,260,479$ & 0.077 \\
\hline
\end{tabular}


Table 6: Summary statistics of groundwater depletion (GWD) [ $\left.\mathrm{km}^{3}\right]$ embedded in domestic transfers and international exports by SCTG commodity group. The total, mean, and variance of GWD in state transfers and exports is provided for each commodity group.

\begin{tabular}{lllllll}
\hline & $\begin{array}{l}\text { SCTG2 } \\
\text { transfers }\end{array}$ & $\begin{array}{l}\text { SCTG2 } \\
\text { exports }\end{array}$ & $\begin{array}{l}\text { SCTG3 } \\
\text { transfers }\end{array}$ & $\begin{array}{l}\text { SCTG3 } \\
\text { exports }\end{array}$ & $\begin{array}{l}\text { SCTG4 } \\
\text { transfers }\end{array}$ & $\begin{array}{l}\text { SCTG4 } \\
\text { exports }\end{array}$ \\
\hline 2002 Total & 5.34 & 0.89 & 9.95 & 1.32 & 11.06 & 0.50 \\
2002 Mean & 0.1067 & 0.0178 & 0.1990 & 0.0265 & 0.2211 & 0.0099 \\
2002 Variance & 0.0893 & 0.0057 & 0.5776 & 0.0113 & 0.4062 & 0.0014 \\
\hline 2012 Total & 8.46 & 0.86 & 12.58 & 1.66 & 13.76 & 1.22 \\
2012 Mean & 0.1692 & 0.0172 & 0.2515 & 0.0333 & 0.2753 & 0.0243 \\
2012 Variance & 0.1539 & 0.0043 & 0.9332 & 0.0171 & 0.5671 & 0.0092 \\
\hline
\end{tabular}


Table 7: Top outflow and inflow regions in 2012. Units are in $\mathrm{km}^{3}$. 'Out-flows' indicates depletion water transfers (DWT) out of a state; 'Exports' indicates depletion water exports (DWE) out of a state; 'In-transfers' indicates depletion water transfers (DWT) into a state; and 'Imports' indicates depletion water exports (DWE) from the US to their recipient world countries and/or regions. Note that state-level self-loops are included in both outflow and inflow categorization.

\begin{tabular}{lllll}
\hline Rank & State & Out-Transfers & State & Exports \\
\hline 1 & California & 13.10 & California & 1.79 \\
2 & Texas & 4.70 & Texas & 0.86 \\
3 & Colorado & 2.61 & Washington & 0.37 \\
4 & Nebraska & 2.41 & Arizona & 0.22 \\
5 & Arizona & 2.25 & Utah & 0.08 \\
6 & Idaho & 1.93 & Kansas & 0.06 \\
7 & Utah & 1.07 & Nebraska & 0.05 \\
8 & New Mexico & 1.03 & Oregon & 0.05 \\
9 & Kansas & 0.98 & Arkansas & 0.04 \\
10 & Arkansas & 0.97 & Illinois & 0.03 \\
\hline Rank & State & In-Transfers & World region & Imports \\
\hline 1 & California & 12.86 & East Asia & 1.62 \\
2 & Texas & 4.64 & Canada & 0.57 \\
3 & Colorado & 2.41 & Mexico & 0.44 \\
4 & Idaho & 2.15 & Southwest and Central Asia & 0.38 \\
5 & Nebraska & 2.14 & Southeast Asia & 0.23 \\
6 & Arizona & 1.82 & Africa & 0.22 \\
7 & New Mexico & 0.97 & Europe & 0.17 \\
8 & Arkansas & 0.87 & Rest of the Americas & 0.12 \\
9 & Kansas & 0.74 & & \\
10 & Wyoming & 0.70 & & \\
\hline
\end{tabular}


Table 8: Total mass and value of transfers and exports reliant on GWD. Mass transfer Value transfer Mass export Value export [kilotonnes] [million \$USD] [kilotonnes] [million \$USD]

\begin{tabular}{lllll}
\hline 2002 & $1,491,126$ & 340,407 & 119,048 & 47,036 \\
2012 & $1,412,242$ & 523,926 & 94,247 & 61,808 \\
\hline
\end{tabular}


Table 9: Ranks of origin-destination flows that rely most on GWD. The top 10 links that are most reliant on GWD in terms of both mass and value are provided.

\begin{tabular}{|c|c|c|c|c|}
\hline Rank & Link & $\begin{array}{l}\text { Mass transfer } \\
\text { [kilotonnes] }\end{array}$ & Link & $\begin{array}{l}\text { Value transfer } \\
{[\text { million } \$ U S D]}\end{array}$ \\
\hline 1 & Iowa-Iowa & 128,610 & California-California & 45,075 \\
\hline 2 & Illinois-Illinois & 103,195 & Iowa-Iowa & 34,874 \\
\hline 3 & Minnesota-Minnesota & 101,052 & Illinois-Illinois & 29,580 \\
\hline 4 & Nebraska-Nebraska & 98,407 & Minnesota-Minnesota & 24,481 \\
\hline 5 & California-California & 66,759 & Nebraska-Nebraska & 21,838 \\
\hline 6 & Kansas-Kansas & 60,897 & Texas-Texas & 19,691 \\
\hline 7 & North Dakota-North Dakota & 50,573 & Kansas-Kansas & 14,997 \\
\hline 8 & Texas-Texas & 45,758 & Indiana-Indiana & 13,079 \\
\hline 9 & South Dakota-South Dakota & 42,385 & North Dakota-North Dakota & 12,902 \\
\hline 10 & Indiana-Indiana & 39,653 & Florida-Florida & 12,383 \\
\hline Rank & Link & $\begin{array}{l}\text { Mass export } \\
\text { [kilotonnes] }\end{array}$ & Link & $\begin{array}{l}\text { Value export } \\
{[\text { million } \$ \mathrm{USD}]}\end{array}$ \\
\hline 1 & Washington-E Asia & 23,209 & Washington-E Asia & 9,614 \\
\hline 2 & Oregon-E Asia & 5,260 & California-E Asia & 5,248 \\
\hline 3 & Illinois-E Asia & 4,710 & California-Canada & 2,886 \\
\hline 4 & California-E Asia & 4,282 & California-Europe & 2,309 \\
\hline 5 & Washington-SE Asia/Oceania & 3,268 & Oregon-E Asia & 1,822 \\
\hline 6 & Iowa-Mexico & 3,014 & Illinois-E Asia & 1,776 \\
\hline 7 & Texas-Mexico & 2,633 & Texas-E Asia & 1,733 \\
\hline 8 & California-Canada & 2,391 & California-SW/Central Asia & 1,643 \\
\hline 9 & Illinois-SE Asia/Oceania & 1,967 & Texas-Mexico & 1,586 \\
\hline 10 & Nebraska-Mexico & 1,964 & Iowa-Mexico & 1,344 \\
\hline
\end{tabular}


A

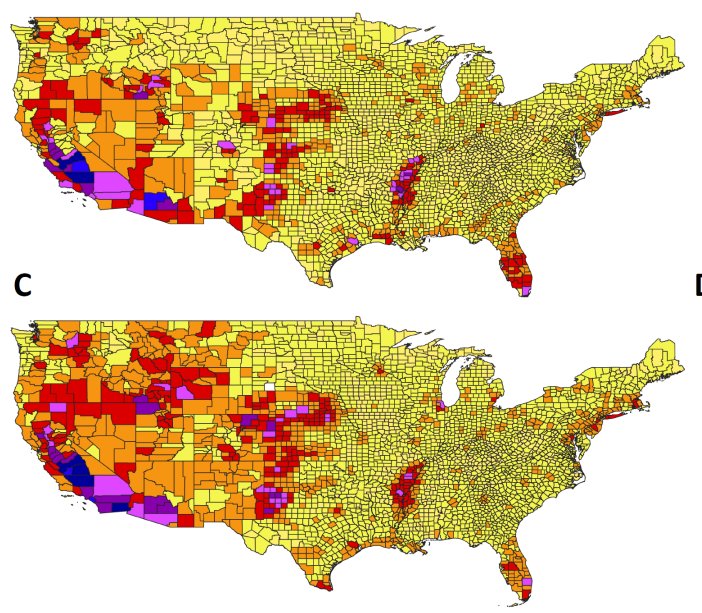

B

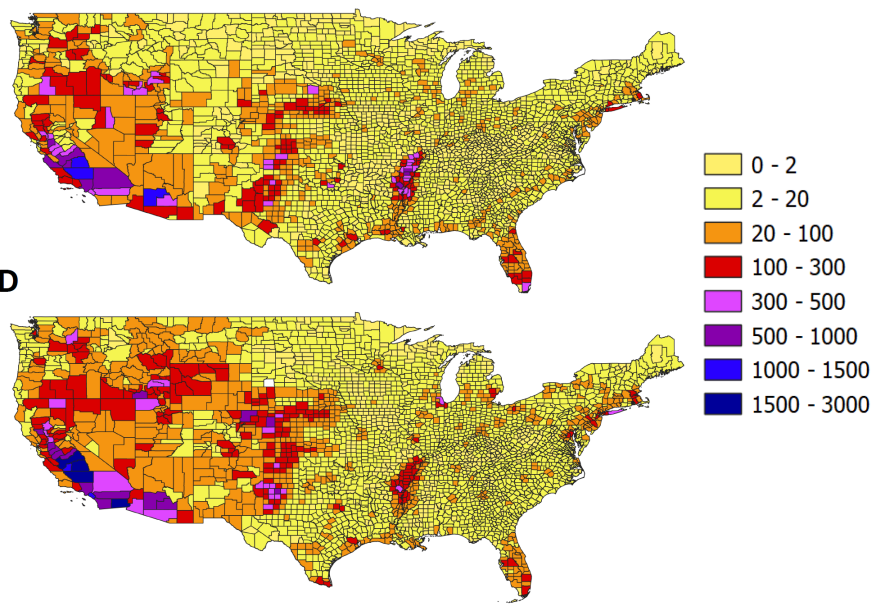

Figure 1: Maps of groundwater abstraction in the United States. Groundwater abstractions $\left[\mathrm{m}^{3} \times 10^{6}\right]$ for each U.S. county is shown for the year 2000 in the first column (Panel A, C) and 2010 in the second column (Panel B, D). Groundwater withdrawals from the U.S. Geological Survey (Hutson et al., 2004; Maupin et al., 2014) are mapped in the first row (Panel A, B). Groundwater abstractions modeled by PCR-GLOBWB are mapped in the second row (Panel C, D). Note that PCR-GLOBWB captures the spatial and time trend of U.S. Geological Survey data to a reasonable degree. 

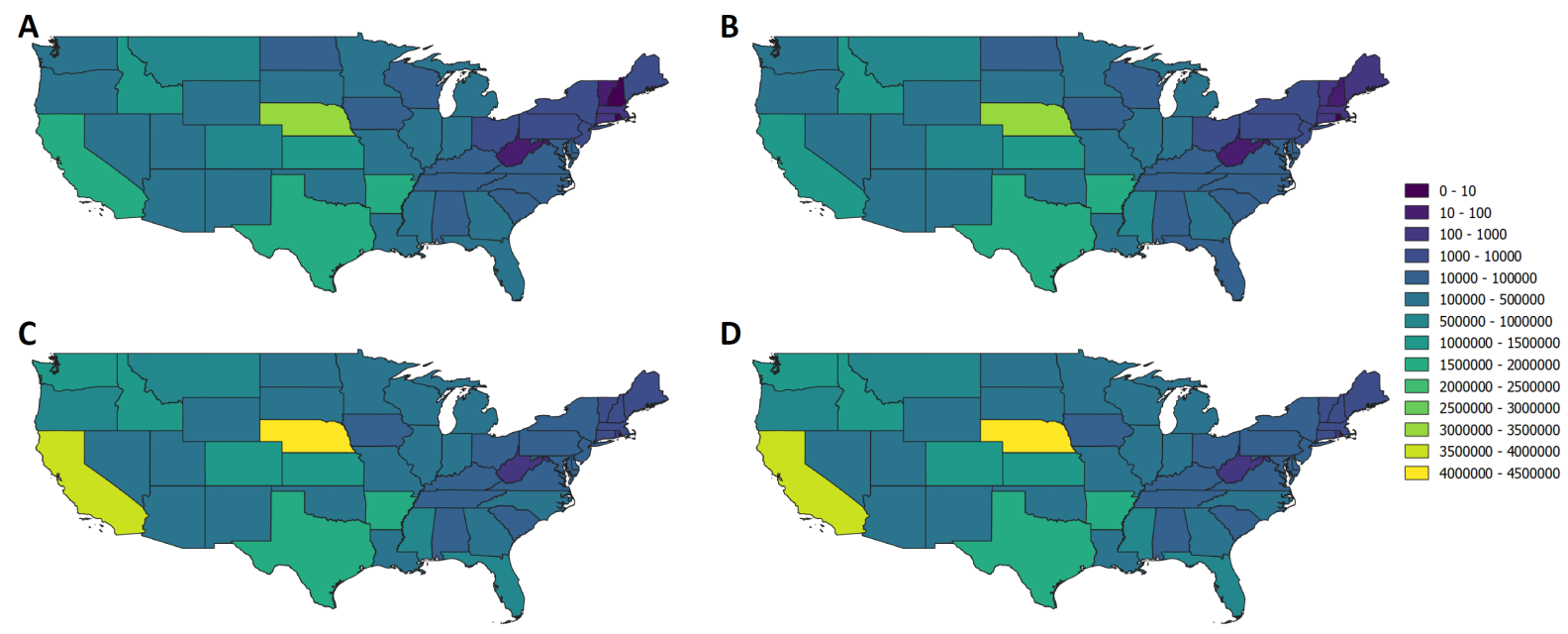

Figure 2: Map of irrigated areas [hectares] in the United States. The top row (Panel A, B) shows USDA data. The bottom row (Panel C, D) shows MIRCA data. The first column (Panel A, C) shows 2000 and the second row (Panel B, D) shows 2010. 'Irrigated Harvest Area' from USDA-NASS Quickstats is mapped for the following crops: Corn (grain and silage), Cotton, Hay \& Haylage, Oats, Peanuts, Southern peas (cowpeas), Rye, Sorghum (grain, silage, and syrup), Soybeans, Wheat, Grasses \& Legumes, Barley, Beans (excluding chickpeas and lima), Camelina, Jojoba, Peas, Popcorn, Triticale, Rice, Buckwheat, Canola, Dill, Flaxseed, Herbs (dry), Hops, Vetch Legumes, Millet (proso), Mint, Safflower, Sesame, Sugarbeets, Sunflower, Switchgrass, Wild rice, Emmer \& spelt, Tobacco, Sugarcane, Legumes, Ginger root, Pineapples, Taro, Mustard seed, Miscanthus, Lentils, Rapeseed, Guar, Potatoes, Sweet potatoes, Ginseng, Sweet rice, Lotus root, and Other Field Crops. The maps of total irrigated area compares reasonably well in space and time across data sources. 


\section{Groundwater Trends}

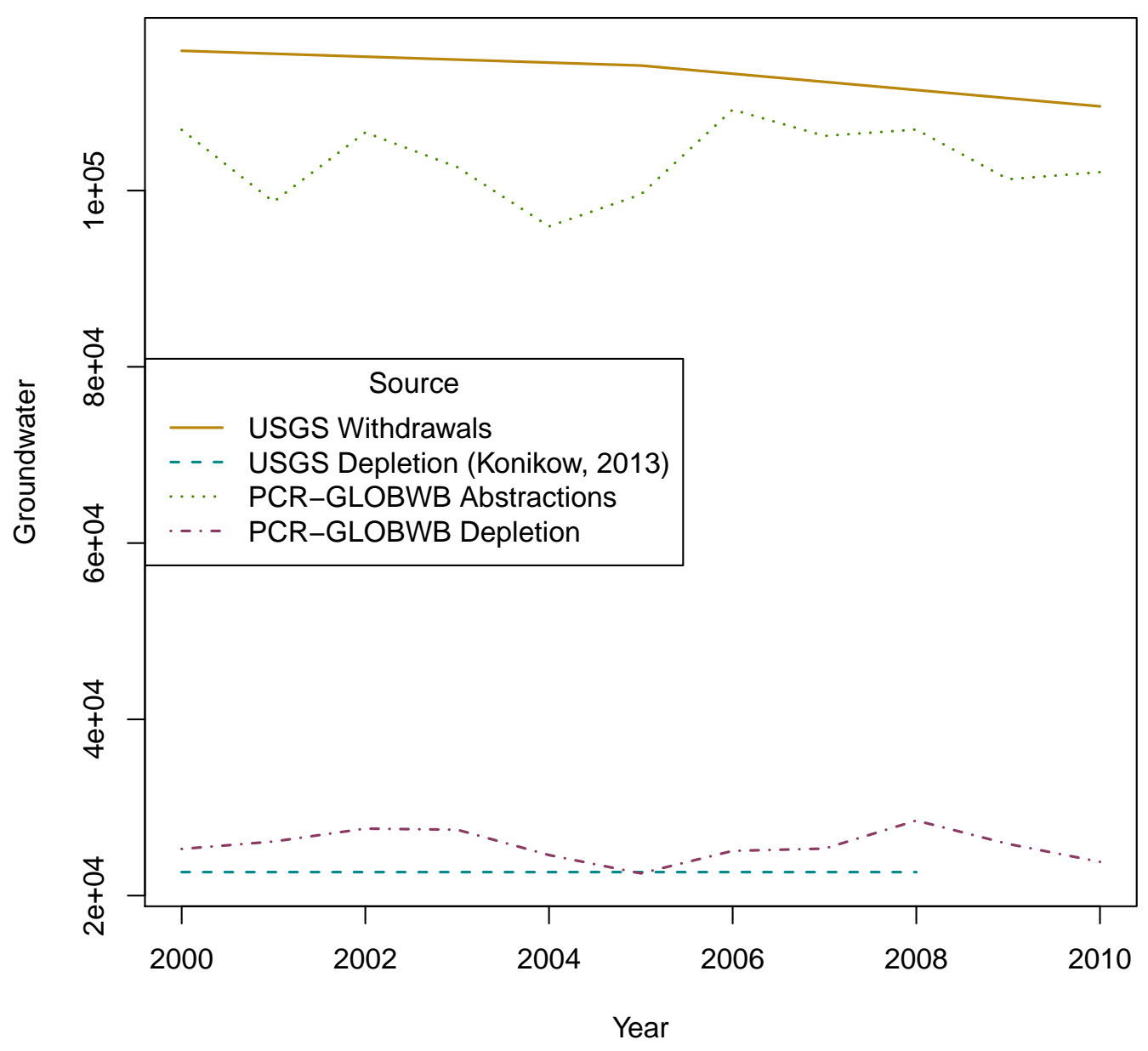

Figure 3: Time series of national groundwater use [Mm3/year]. USGS groundwater withdrawals is compared with groundwater abstractions from PCR-GLOBWB. A trend line is fit to USGS withdrawals for 2000, 2005, and 2010. USGS annual groundwater depletion for major aquifers is calculated from Konikow (2013). This was calculated as the difference between the groundwater depletion volume from 1900-2008 vs. 1900-2000. This difference was then divided by 9 and attributed to each of the nine years from 2000-2008. USGS groundwater depletion is compared with PCR-GLOBWB groundwater depletion. The national trends compare reasonably well between the USGS data and the PCR-GLOBWB model estimates. 



Figure 4: Maps of groundwater depletion in the United States. Groundwater depletion $\left[\mathrm{m}^{3} \times 10^{6}\right]$ for each U.S. county is shown for the year 2010 (Panel A). Changes from 2000 to 2010 are mapped in Panel B. 

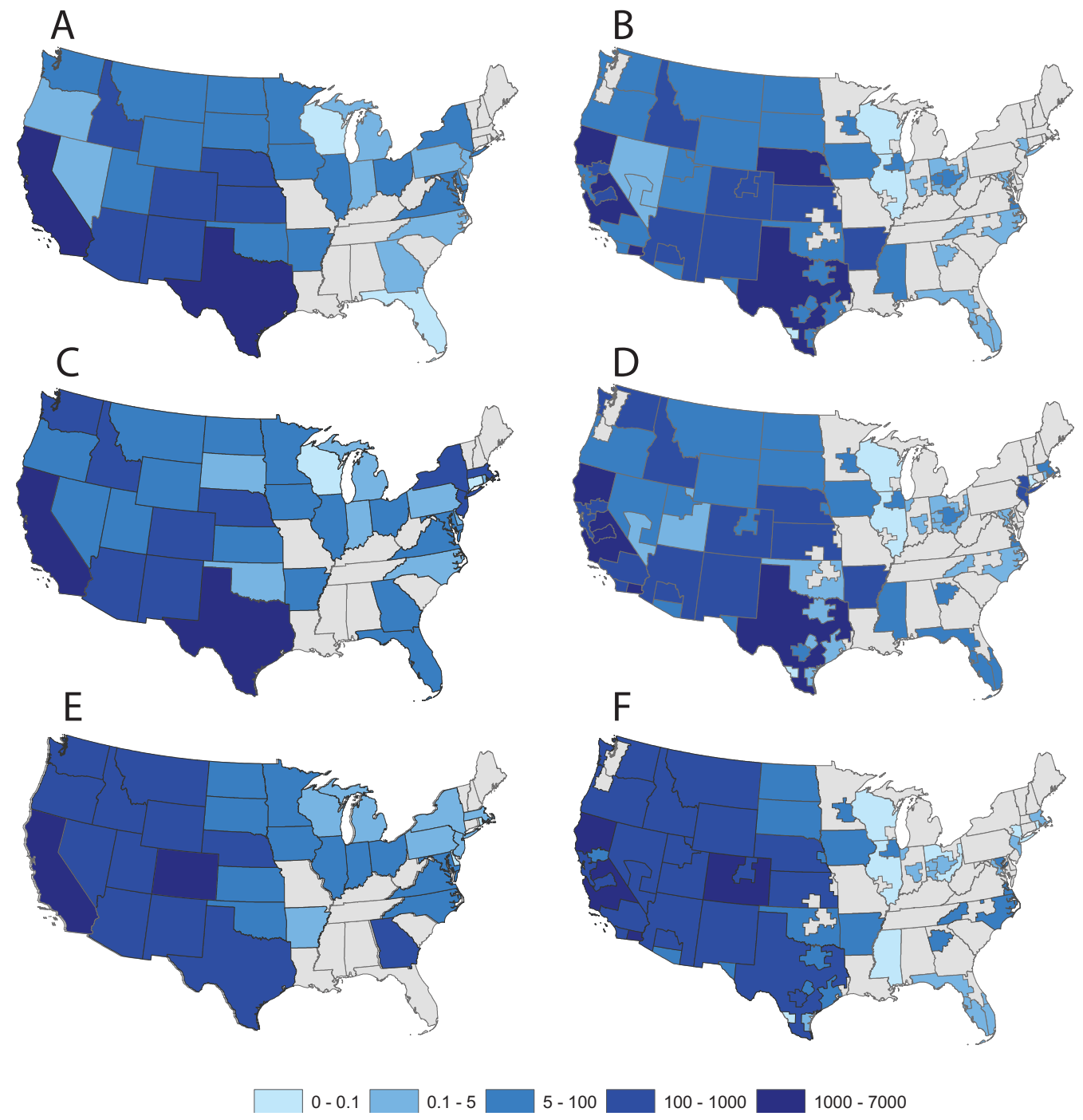

Figure 5: Maps of groundwater depletion transfers within the United States. Groundwater depletion out-flows $\left[10^{6} \mathrm{~m}^{3}\right.$ year $\left.^{-1}\right]$ are provided for each agricultural commodity class considered in this study. The first row (Panels A, B) shows grains (SCTG 2); the second row (Panels C, D) shows fresh produce (SCTG 3); and the third row (Panels E, F) shows animal feed (SCTG 4). The first column (Panels A, C, E) shows the year 2000 and the second column (Panels B, D, F) shows the year 2010. Note that domestic transfers are calculated at the state spatial scale in 2002 and the FAF zone spatial scale in 2012. 

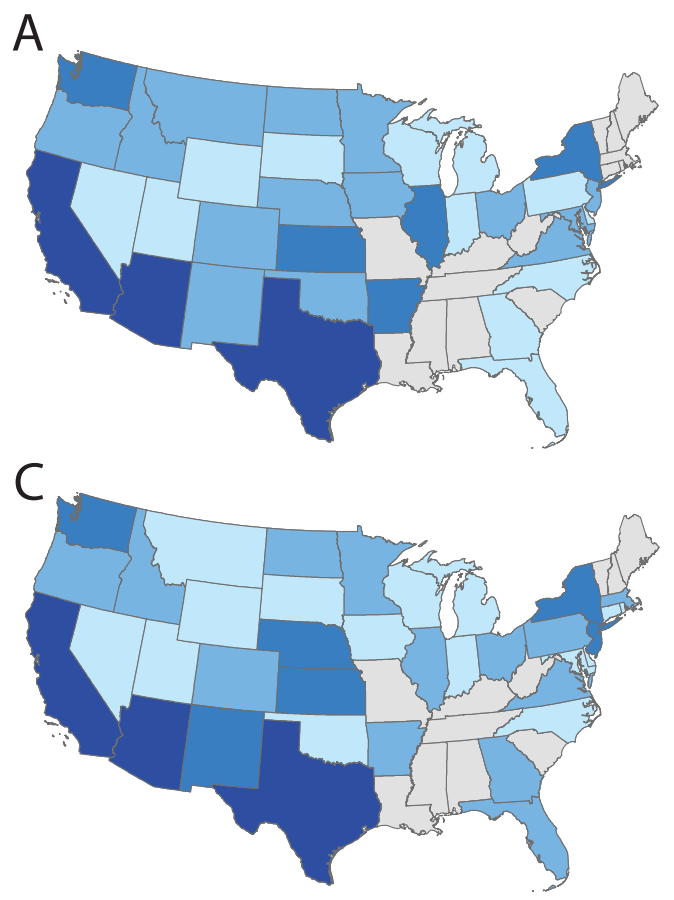

E

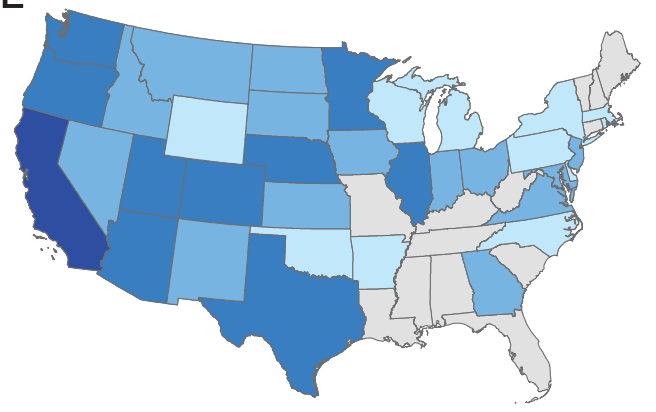

B

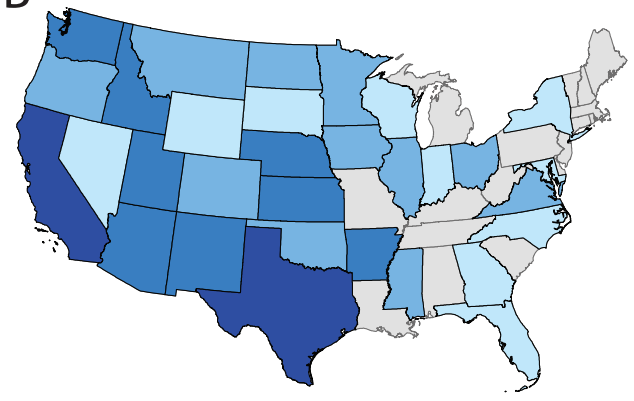

D

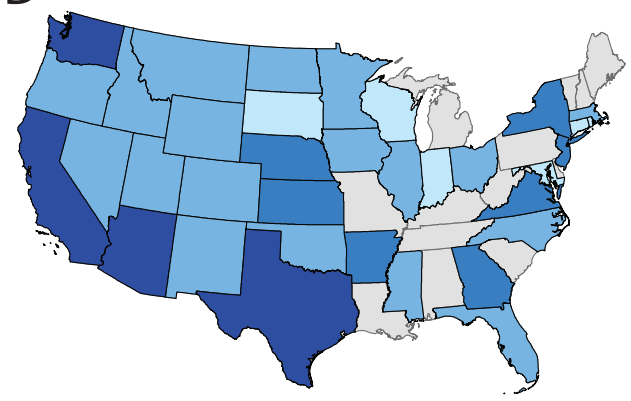

$\mathrm{F}$

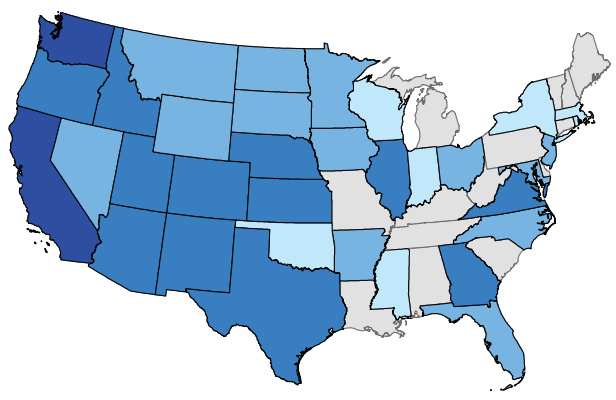

$5-100$ $100-1000$ $1000-7000$

Figure 6: Maps of groundwater depletion exports from the United States. Exports of groundwater depletion $\left[10^{6} \mathrm{~m}^{3}\right.$ year $\left.^{-1}\right]$ are provided at the state spatial scale and for each agricultural commodity class considered in this study. The top row (Panels A, B) shows the groundwater depletion exports of grains (SCTG 2), the middle row (Panels C, D) shows the groundwater depletion exports of fresh produce (SCTG 3), and the bottom row (Panels E, F) shows the groundwater depletion exports of animal feed (SCTG 4). The first column (Panels A, C, E) shows groundwater depletion exports in 2002. The second column (Panels B, D, and F) shows groundwater depletion exports in 2012. 


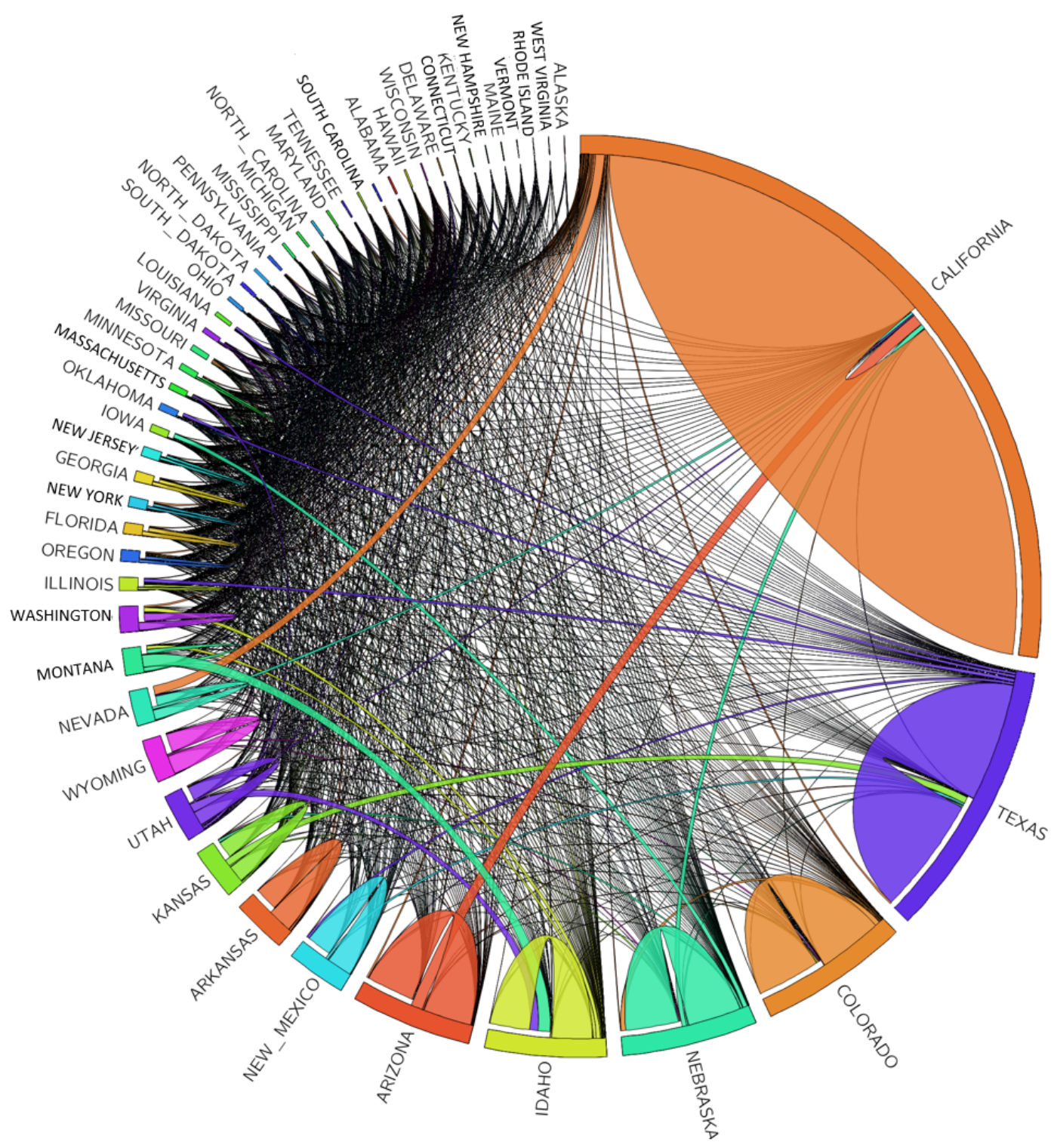

Figure 7: Circos graph of domestic groundwater depletion transfers in 2012. States are plotted clockwise in descending order of their total groundwater depletion volume embedded in their commodity outflows. The size of the length of arc around the circle indicates the total volume of each state as a percentage of total domestic transfers. Outflow volume is indicated with links emanating from the arc of the same color. Inflow volume is indicated with a white area separating the arc from links of a different color. The volume of groundwater depletion captured in this graph is $34.8 \mathrm{~km}^{3} \mathrm{yr}^{-1}$. 



Figure 8: Circos graph of changes in groundwater depletion transfers. Positive (A) and negative $(\mathrm{B})$ values are shown for domestic transfers. The total volume graphed in Panel A is $11.8 \mathrm{~km}^{3} \mathrm{yr}^{-1}$ and the total volume graphed in Panel B is $3.4 \mathrm{~km}^{3} \mathrm{yr}^{-1}$. In 2012, Colorado is using more of its own groundwater depletion, but sending less to other states. 




Figure 9: Circos graph of international groundwater depletion exports in 2012. States and world regions are plotted clockwise in descending order of the total groundwater depletion volume embedded in their commodity trade. International export volume is indicated with links emanating from the outer bar of the same color. The volume of groundwater depletion captured in this graph is $3.7 \mathrm{~km}^{3} \mathrm{yr}^{-1}$. 

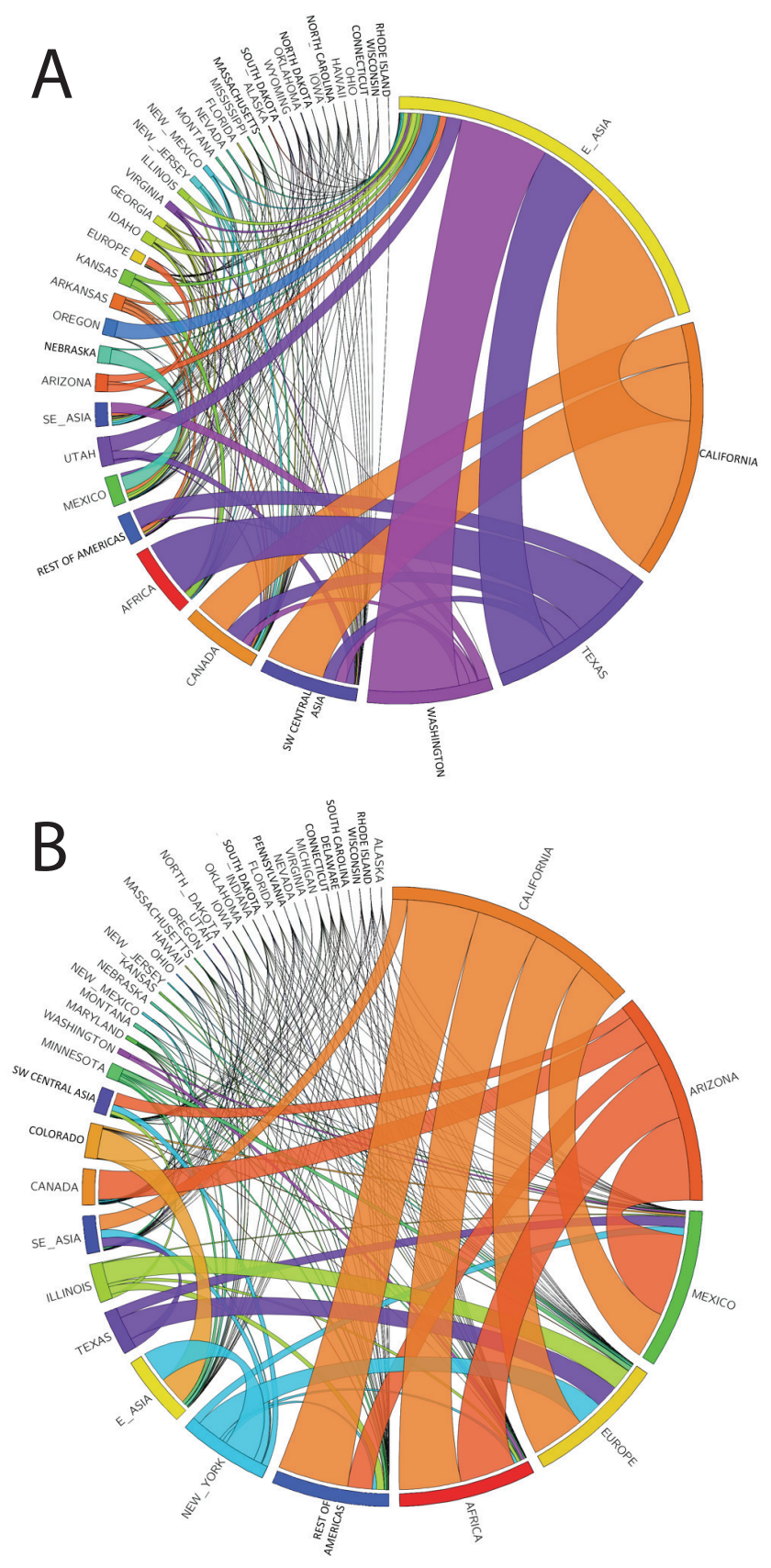

Figure 10: Circos graph of changes in groundwater depletion exports. Positive (A) and negative (B) values are shown for international exports. The total volume graphed in Panel $\mathrm{A}$ is $1.7 \mathrm{~km}^{3} \mathrm{yr}^{-1}$ and the total volume graphed in Panel $\mathrm{B}$ is $0.66 \mathrm{~km}^{3} \mathrm{yr}^{-1}$. In 2012, California is sending more virtual groundwater depletion to Eastern Asia and less to Europe. 